Article

\title{
Antitumor and Immunoregulatory Activities of Seleno- $\beta$-Lactoglobulin on S180 Tumor-Bearing Mice
}

\author{
Su-jun Sun ${ }^{\dagger}$, Ying-ying Feng ${ }^{\dagger}$, Yan Zhang ${ }^{*}{ }^{\dagger}$, Hai-yu Ji, Juan Yu and An-jun Liu * \\ Key Laboratory of Food Nutrition and Safety, Ministry of Education, School of Food Engineering and \\ Biotechnology, Tianjin University of Science and Technology, Tianjin 300457, China; jihaiyu1247@163.com (S.-j.S.); \\ gfengyingying@foxmail.com (Y.-y.F.); haiyu11456@163.com (H.-y.J.); yujuan14615@163.com (J.Y.) \\ * Correspondence: cpzyyan@126.com (Y.Z.); laj1456@163.com (A.-j.L.) \\ + These authors contributed equally to this work.
}

Received: 17 November 2017; Accepted: 24 December 2017; Published: 28 December 2017

\begin{abstract}
Degeneration of immune organs like thymus and spleen has been discovered in tumor-bearing mice; which increases the difficulties on oncotherapy. More effective drugs which target the protection of immune organs are expected to be researched. In this study; we aim to analyze the antitumor and immunoregulatory activities of seleno- $\beta$-lactoglobulin (Se- $\beta$-lg) on S180 tumor-bearing mice. Results indicated that Se- $\beta$-lg exhibited a remarkable inhibitory effect on S180 solid tumors with the inhibition rate of $48.38 \%$; and protected the thymuses and spleens of S180-bearing mice. In addition, Se- $\beta$-lg could also balance the proportions of $\mathrm{CD}^{+}$and $\mathrm{CD} 8^{+} \mathrm{T}$ cells in spleens; thymuses and peripheral bloods; and improve Levels of IL-2; IFN- $\gamma$; TNF- $\alpha$ in mice serums. $\beta$-lg showed weaker bioactivities while $\mathrm{SeO}_{2}$ showed stronger toxicity on mice. Therefore our results demonstrated that Se- $\beta$-lg possessed stronger antitumor and immunoregulatory activities with lower side effects and had the potential to be a novel immunopotentiator and antitumor agent.
\end{abstract}

Keywords: seleno- $\beta$-lactoglobulin; S180 tumor-bearing mice; antitumor; immunoregulation

\section{Introduction}

Selenium is essential for the body due to the regulation on activity of seleno-enzyme-glutathione peroxidase [1,2]. Se plays critical roles in various physiological processes, which is associated with anticarcinogenesis, antioxidantion, immunoenhancement [3-5] and widely used as a dietary supplement, particularly [6-9]. Mao [10] found polysaccharide termed Se-GP11, extracted and purified from Se-enriched Grifola frondosa exhibited the antitumor effect through improving immunologic function of the tumor bearing mice. Yuan [11] had proved that Se-PFPs could significantly reduce tumors growth on nude mice bearing MDA-MB-231-derived xenograft tumors without toxic side effects.

$\beta$-Lactoglobulin $(\beta-\mathrm{lg})$, the dominant whey protein in bovine milk, is an $18.4 \mathrm{kDa}$ globular lipocalin protein that consists of 162 amino acid residues with a pI of approximately 5.4 [12-14]. $\beta-1 \mathrm{~g}$ is folded into a calyx formed by eight antiparallel b-strands and one a-helix at the outer surface of the b-barrel [15]. The unique structural character makes $\beta$-lg aggregate forming nanoparticles and when electrically charged, $\beta-\lg$ is able to bind various ligands and form electrostatic complexes [16]. $\beta$-lg nanoparticles have been applied for drug targeting such as beta casein nanoparticles for targeting gastric cancer and albumin conjugated nanoparticles for effective in vivo drug delivery across the blood-brain barrier [17].

In our previous study, a novel agent, seleno- $\beta$-lactoglobulin (Se- $\beta-\lg )$ was synthesized by introducing selenic acid groups to arginine and lysine's primary amine in $\beta$-lg (applying for Chinese patent, No. 201410820824.3). The present study was designed to investigate the antitumor and immunoregulatory activities of Se- $\beta$-lg on S180 tumor-bearing mice. 


\section{Results and Discussion}

\subsection{Immune Organ Indexes and Tumor Inhibition Rate of Se- $\beta$-lg}

As shown in Table 1, thymus index of tumor-bearing mice was significantly descended than that in normal group, while spleen index was obviously increased, which were consistent with previous finding $[18,19]$, indicating that the proliferation of malignant neoplasm could damage the immune system severely by forming a micro-environment favorable for tumors growth, resulting in the splenomegaly and thymic atrophy. Results showed that Se- $\beta$-lg could significantly protect the immune organs in S180-bearing mice, while $\mathrm{SeO}_{2}$ exhibited serious toxic side effects due to the remarkable decrease compared with model group. The average tumor weight of model group was $2.79 \pm 0.28$ g. $\beta-\mathrm{lg}, \mathrm{SeO}_{2}$ and three $\mathrm{Se}-\beta-\mathrm{lg}$ groups showed remarkable inhibition effects on the growth of the S180 tumor compared to the model group with inhibitory rates of $21.51 \%, 53.05 \%, 20.79 \%$, $45.88 \%$ and $48.38 \%$ respectively. These results indicated that $\mathrm{SeO}_{2}$ had strong killing effects of S180 cells in vivo with serious side effects, while Se- $\beta$-lg not only showed greater antitumor activity in S180-bearing mice than $\beta-\mathrm{lg}$, but also possessed lower toxicity than $\mathrm{SeO}_{2}$.

Table 1. Immune organ indexes and tumor inhibition rate of Se- $\beta$-lg.

\begin{tabular}{|c|c|c|c|c|c|}
\hline \multirow{2}{*}{ Treatment } & Dose & Thymus Index & Spleen Index & Tumor Weight & Inhibitory Rate \\
\hline & $(\mu \mathrm{g} / \mathrm{kg})$ & $(\mathrm{mg} / \mathrm{g})$ & $(\mathrm{mg} / \mathrm{g})$ & (g) & $(\%)$ \\
\hline $\mathrm{N}$ & - & $3.21 \pm 0.36$ & $4.89 \pm 0.31$ & - & - \\
\hline M & - & $1.63 \pm 0.14^{\mathrm{a}}$ & $8.16 \pm 0.21^{\mathrm{a}}$ & $2.79 \pm 0.28$ & - \\
\hline$\beta-\lg$ & 150 & $1.98 \pm 0.14^{b}$ & $6.47 \pm 0.31^{\mathrm{b}}$ & $2.19 \pm 0.12^{b}$ & 21.51 \\
\hline $\mathrm{SeO}_{2}$ & 100 & $1.33 \pm 0.11^{b}$ & $3.17 \pm 0.13^{b}$ & $1.31 \pm 0.11^{b}$ & 53.05 \\
\hline L-Se- $\beta-\lg$ & 50 & $1.94 \pm 0.12^{b}$ & $6.48 \pm 0.41^{b}$ & $2.21 \pm 0.19^{b}$ & 20.79 \\
\hline M-Se- $\beta-\lg$ & 100 & $2.76 \pm 0.28^{b}$ & $5.38 \pm 0.42^{b}$ & $1.51 \pm 0.10^{b}$ & 45.88 \\
\hline H-Se- $\beta-\lg$ & 150 & $3.18 \pm 0.36^{b}$ & $4.72 \pm 0.21^{b}$ & $1.44 \pm 0.12^{b}$ & 48.38 \\
\hline
\end{tabular}

\subsection{T Lymphocyte Subpopulation of Thymus and Spleen}

The two major subsets of T lymphocytes are defined by expression of CD4 or CD8 glycoproteins respectively [20]. $\mathrm{CD}^{+} \mathrm{T}$ cells play an important role in orchestrating the antitumor response by imparting cytolytic activity and cytokine expression. Tumor-bearing patients with massive infiltrated $\mathrm{CD}^{+} \mathrm{T}$ cells would have a better clinical outcome generally [21,22]. CD4 ${ }^{+} \mathrm{T}$ cells could recruit and activate innate immune cells such as natural killer cells and macrophages in anti-tumor immunity [23].

Results of proportions of $\mathrm{T}$ cell subsets in spleen were showed in Table 2. CD4 ${ }^{+}$and CD8 ${ }^{+}$ $\mathrm{T}$ lymphocytes of tumor-bearing mice were remarkable decreased compared with normal mice. The proportion of $\mathrm{T}$ cells in $\mathrm{SeO}_{2}$ groups were even lower than that in model group, which indicated that $\mathrm{SeO}_{2}$ would promote the apoptosis of $\mathrm{T}$ cells in spleen and aggravate splenic injury, while $\beta$-lg and Se- $\beta$-lg could significantly balance the disorder of T lymphocytes, especially in high dosage of Se- $\beta$-lg group. The proportion of $\mathrm{CD}^{+} \mathrm{T}$ cells and $\mathrm{CD}^{+} \mathrm{T}$ cells reached $63.25 \%$ and $13.21 \%$ in Se- $\beta-1 \mathrm{~g}$ high dosage group, which indicated that Se- $\beta-\lg$ had the ability to effectively reduce the damage of malignant tumors.

As shown in Table 2, the proportions of $\mathrm{T}$ cell subsets in thymus were significantly increased in tumor bearing mice compared to normal group, maybe because the proliferation of tumor cells in vivo could accelerate the differentiation and proliferation of thymocytes as an immune response. Proportions of $\mathrm{CD}^{+}$and $\mathrm{CD}^{+} \mathrm{T}$ cells in medicine treatment groups were all decreased obviously compared with model group, particularly in Se- $\beta-\lg$ high dosage group with the proportion of CD $4^{+}$ and $\mathrm{CD}^{+} \mathrm{T}$ cells being $20.21 \%$ and $16.23 \%$. However, $\mathrm{CD}^{+} \mathrm{T}$ cell subsets in $\mathrm{SeO}_{2}$ group were $14.02 \%$ which were significant lower than that in normal group due to the toxic effects of $\mathrm{SeO}_{2}$ on both 
tumor cells and immune organs. Our results indicated that the Se- $\beta$-lg could effectively balance the population of $\mathrm{T}$ cells subsets in thymus and spleen of tumor-bearing mice, which would enhance the antitumor immunity.

Table 2. T lymphocyte subpopulation in spleen and thymus.

\begin{tabular}{|c|c|c|c|c|}
\hline \multirow{2}{*}{ Treatment } & \multicolumn{2}{|c|}{ Spleen } & \multicolumn{2}{|c|}{ Thymus } \\
\hline & CD4/(\%) & CD8/(\%) & CD4/(\%) & CD8/(\%) \\
\hline $\mathrm{N}$ & $67.01 \pm 6.19$ & $15.13 \pm 1.21$ & $17.07 \pm 1.19$ & $11.21 \pm 1.23$ \\
\hline M & $50.21 \pm 3.25^{\mathrm{a}}$ & $8.52 \pm 0.88^{a}$ & $28.21 \pm 2.24^{\mathrm{a}}$ & $21.52 \pm 1.88^{a}$ \\
\hline$\beta-\lg$ & $54.36 \pm 4.12^{b}$ & $11.22 \pm 1.73^{b}$ & $24.89 \pm 2.12^{b}$ & $19.22 \pm 1.73^{b}$ \\
\hline $\mathrm{SeO}_{2}$ & $44.02 \pm 3.07^{b}$ & $6.22 \pm 0.82^{b}$ & $14.02 \pm 1.07^{b}$ & $13.15 \pm 1.22^{b}$ \\
\hline L-Se- $\beta-\lg$ & $53.98 \pm 4.16$ & $12.44 \pm 1.12^{b}$ & $23.98 \pm 2.23^{b}$ & $21.44 \pm 2.16$ \\
\hline M-Se- $\beta-\lg$ & $61.68 \pm 3.41^{b}$ & $13.27 \pm 1.14^{b}$ & $21.68 \pm 2.41^{b}$ & $17.28 \pm 1.23^{b}$ \\
\hline H-Se- $\beta-\lg$ & $63.25 \pm 5.25^{b}$ & $13.21 \pm 1.19^{b}$ & $20.31 \pm 2.25^{b}$ & $16.23 \pm 1.48^{b}$ \\
\hline
\end{tabular}

\subsection{T Lymphocyte Subpopulation of Tumor and Peripheral Blood}

As shown in Table 3, after inoculation of tumor cells, the proportions of CD4 ${ }^{+}$and $\mathrm{CD}^{+} \mathrm{T}$ cells in peripheral blood of model group were reduced significantly compared to normal group, while only $\mathrm{CD}^{+} \mathrm{T}$ cells were found in solid tumors. After dealt with $\beta-\lg$ and Se- $\beta-\lg$, the proportions of CD4 ${ }^{+}$ and $\mathrm{CD}^{+} \mathrm{T}$ cells were significantly increased in peripheral blood, especially in $\mathrm{H}-\mathrm{Se}-\beta-\lg$ group, which indicated their ability of tumor inhibition effects by regulating $\mathrm{T}$ cells immune function. Compared to model group, $\mathrm{CD}^{+} \mathrm{T}$ cell and $\mathrm{CD} 8^{+} \mathrm{T}$ cell in peripheral blood were obviously decreased in $\mathrm{SeO}_{2}$ group, suggesting its cytotoxicity on body cells, considering the significant tumors inhibition effect. The results of proportions of $\mathrm{CD}^{+} \mathrm{T}$ cells in solid tumors with no significant intergroup difference indicated that the recognition capability of $\mathrm{CD}^{+} \mathrm{T}$ cells might exhibit greater antitumor effect.

Table 3. T lymphocyte subpopulation of peripheral blood and tumor.

\begin{tabular}{ccccc}
\hline \multirow{2}{*}{ Treatment } & \multicolumn{2}{c}{ Peripheral Blood } & \multicolumn{2}{c}{ Solid Tumor } \\
\cline { 2 - 5 } & CD4/(\%) & CD8/(\%) & CD4/(\%) & CD8/(\%) \\
\hline $\mathrm{N}$ & $42.22 \pm 3.17$ & $23.01 \pm 2.19$ & - & - \\
$\mathrm{M}$ & $28.63 \pm 2.11^{\mathrm{a}}$ & $18.52 \pm 1.12^{\mathrm{a}}$ & $0.09 \pm 0.003$ & $41.52 \pm 3.12$ \\
$\beta-1 \mathrm{lg}$ & $32.79 \pm 3.25^{\mathrm{b}}$ & $19.88 \pm 1.14^{\mathrm{b}}$ & $0.12 \pm 0.003$ & $40.24 \pm 3.11$ \\
$\mathrm{SeO} 2$ & $24.02 \pm 2.11^{\mathrm{b}}$ & $16.04 \pm 1.12^{\mathrm{b}}$ & $0.14 \pm 0.002$ & $38.41 \pm 2.21$ \\
$\mathrm{~L}-\mathrm{Se}-\beta-1 \mathrm{lg}$ & $31.98 \pm 2.20^{\mathrm{b}}$ & $21.11 \pm 1.16^{\mathrm{b}}$ & $0.12 \pm 0.004$ & $39.87 \pm 3.29$ \\
$\mathrm{M}-\mathrm{Se}-\beta-\mathrm{lg}$ & $38.68 \pm 3.21^{\mathrm{b}}$ & $21.28 \pm 2.19^{\mathrm{b}}$ & $0.13 \pm 0.003$ & $41.01 \pm 2.41$ \\
$\mathrm{H}-\mathrm{Se}-\beta-\lg$ & $44.20 \pm 3.24^{\mathrm{b}}$ & $23.19 \pm 1.27^{\mathrm{b}}$ & $0.11 \pm 0.004$ & $38.82 \pm 3.34$ \\
\hline
\end{tabular}

Note: ${ }^{\mathrm{a}} p<0.05$ compared to normal group; ${ }^{\mathrm{b}} p<0.05$ compared to model group.

\subsection{Analysis of Cell Cycle Detection in Tumor Cells}

As shown in Table 4, apoptosis ratio of tumor cells in drug treatment groups were significantly increased compared to model group with $13.21 \%$ in $\beta-1 g, 27.15 \%$ in $\mathrm{SeO}_{2}$, and $24.13 \%$ in Se- $\beta-1 \mathrm{~g}$ high-dosage group. The results showed that the effects of $\mathrm{SeO}_{2}$ and $\mathrm{Se}-\beta-\mathrm{lg}$ on inducing tumors cells apoptosis were better than $\beta-\mathrm{lg}$, which proved the remarkable inhibition effect of $\mathrm{SeO}_{2}$ on tumor cells in vivo, considering the immunosuppressive effect on immune system of tumor-bearing host $\mathrm{SeO}_{2}$ was not appropriate to clinical tumor therapy, while Se- $\beta-1 g$ exhibited better antitumor and immunoregulatory activities. As shown, an accumulation of cell numbers in G0/G1 phase in Se- $\beta$-lg groups was discovered dose-dependently, which indicated that Se- $\beta$-lg could inhibit S180 cells proliferation and promote tumors cells apoptosis by blocking cell cycle in G0/G1 phase in vivo. 
Table 4. Distributions of cell cycle and apoptosis of tumor cell.

\begin{tabular}{ccccc}
\hline Groups & G0/G1/(\%) & S/(\%) & G2/M/(\%) & Apoptosis/(\%) \\
\hline $\mathrm{M}$ & $31.44 \pm 2.35$ & $54.51 \pm 3.12$ & $14.52 \pm 1.63$ & $2.24 \pm 0.32$ \\
$\beta-\lg$ & $42.32 \pm 2.32^{\mathrm{b}}$ & $44.63 \pm 3.42^{\mathrm{b}}$ & $14.34 \pm 1.24$ & $13.21 \pm 1.05^{\mathrm{b}}$ \\
$\mathrm{SeO}$ & $50.21 \pm 3.32^{\mathrm{b}}$ & $34.32 \pm 2.15^{\mathrm{b}}$ & $15.26 \pm 1.22$ & $27.15 \pm 2.53^{\mathrm{b}}$ \\
$\mathrm{L}-\mathrm{Se}-\beta-\lg$ & $38.13 \pm 2.46^{\mathrm{b}}$ & $48.27 \pm 4.13^{\mathrm{b}}$ & $14.47 \pm 1.45$ & $11.32 \pm 1.03^{\mathrm{b}}$ \\
$\mathrm{M}-\mathrm{Se}-\beta-\lg$ & $43.23 \pm 2.12^{\mathrm{b}}$ & $41.32 \pm 3.23^{\mathrm{b}}$ & $13.51 \pm 1.63$ & $18.13 \pm 1.24^{\mathrm{b}}$ \\
$\mathrm{H}-\mathrm{Se}-\beta-\lg$ & $49.11 \pm 3.43^{\mathrm{b}}$ & $36.92 \pm 3.05^{\mathrm{b}}$ & $15.37 \pm 1.35$ & $24.13 \pm 2.12^{\mathrm{b}}$ \\
\hline \multicolumn{5}{c}{ Note: $^{\mathrm{b}} p<0.05$ compared to model group. $^{2}$}
\end{tabular}

\subsection{Cytokine Detection}

Interleukin-2 (IL-2), interferons- $\gamma$ (IFN- $\gamma)$ and tumor necrosis factor- $\alpha$ (TNF- $\alpha)$ are cytokines associated with stimulation and suppression of immune responses and play crucial roles in those pathological processes [24-26]. As shown in Table 5, the IL-2, IFN- $\gamma$ and TNF- $\alpha$ levels in serums of model group were significantly decreased compared to normal group $(p<0.05)$, and those of $\mathrm{SeO}_{2}$ group were even lower than model group, suggesting its immunosuppression function on S180 tumor-bearing mice, which agreed with the data above. while the levels of cytokines in Se- $\beta$-lg were significantly higher than model group, which indicated that Se- $\beta$-lg exhibited a stronger immunoregulatory activity in balancing the levels of these cytokines in vivo with lower toxic side effects.

Table 5. Results of IL-2, IFN- $\gamma$, and TNF- $\alpha$ levels in serums of mice.

\begin{tabular}{cccc}
\hline Treatment & IL-2 $(\mathbf{p g} / \mathbf{m L})$ & IFN- $\gamma(\mathbf{n g} / \mathrm{L})$ & TNF- $\alpha(\mathbf{n g} / \mathrm{L})$ \\
\hline $\mathrm{N}$ & $4.01 \pm 0.19$ & $119.83 \pm 7.01$ & $117.89 \pm 4.07$ \\
$\mathrm{M}$ & $2.52 \pm 0.11^{\mathrm{a}}$ & $112.34 \pm 5.93^{\mathrm{a}}$ & $91.09 \pm 5.99^{\mathrm{a}}$ \\
$\beta-\mathrm{lg}$ & $2.89 \pm 0.15^{\mathrm{b}}$ & $116.71 \pm 4.97$ & $97.77 \pm 7.03$ \\
$\mathrm{SeO} 2$ & $2.02 \pm 0.11^{\mathrm{b}}$ & $100.84 \pm 4.93$ & $80.90 \pm 4.99$ \\
$\mathrm{~L}-\mathrm{Se}-\beta-\lg$ & $2.98 \pm 0.16^{\mathrm{b}}$ & $118.8 \pm 5.98$ & $101.86 \pm 4.04^{\mathrm{b}}$ \\
$\mathrm{M}-\mathrm{Se}-\beta-\mathrm{lg}$ & $3.68 \pm 0.21^{\mathrm{b}}$ & $124.5 \pm 8.03^{\mathrm{b}}$ & $111.56 \pm 3.09^{\mathrm{b}}$ \\
$\mathrm{H}-\mathrm{Se}-\beta-\mathrm{lg}$ & $3.81 \pm 0.25^{\mathrm{b}}$ & $133.03 \pm 7.07^{\mathrm{b}}$ & $120.09 \pm 6.13^{\mathrm{b}}$ \\
\hline
\end{tabular}

\section{Materials and Methods}

\subsection{Animals and Cells}

Kunming SPF mice (female, 8-week-old), body weight 18-22 g, were purchased from the Peking University Health Science Center (Beijing, China), and raised in a temperature and humidity controlled environment under a $12 \mathrm{~h}$ light/12 h dark cycle, and given food and water ad libitum. All mice were acclimatized to the facility for 1 week prior to experiments. All animal experiments were performed following the Animal (Control of Experiments) Ordinance of Laws of China.

Mouse sarcoma S180 cells were obtained from Immunological Laboratory of Tianjin Medical University and maintained in RPMI 1640 medium supplemented with $10 \%$ heat-inactivated fetal bovine serum at $37{ }^{\circ} \mathrm{C}$ in an atmosphere with $5 \% \mathrm{CO}_{2}$ in $60 \mathrm{~mm}$ Petri dishe.

Mice were divided randomly into the following seven groups:

Group 1: Normal (N)

Group 2: Model (M)

Group 3: $\beta-1 g$

Group 4: $\mathrm{SeO}_{2}$

Group 5: Low Se- $\beta$-lg (L-Se- $\beta$-lg) 
Group 6: Middle Se- $\beta$-lg (M-Se- $\beta$-lg)

Group 7: High Se- $\beta$-lg $(\mathrm{H}-\mathrm{Se}-\beta-\lg )$

Sarcoma 180 tumor cells $\left(2 \times 10^{6}\right.$ cells / mouse $)$ were inoculated in the right forelimb armpit of all mice in Group 2 to 7, and empty treatment was done in the control group. 15 days before and after tumor implantation, mice in groups 3-7 were administered, respectively the following $150 \mu \mathrm{g} / \mathrm{kg} \mathrm{lg}$, $100 \mu \mathrm{g} / \mathrm{kg} \mathrm{SeO} 2,50 \mu \mathrm{g} / \mathrm{kg}$ Se$-\beta-\lg , 100 \mu \mathrm{g} / \mathrm{kg}$ Se- $\beta-\lg , 150 \mu \mathrm{g} / \mathrm{kg}$ Se- $\beta-\lg$. Normal and model groups were both applied $0.2 \mathrm{~mL} / \mathrm{d}$ saline solution orally throughout the experimental period. All mice were sacrificed and tumors, thymuses, spleens were cut and blood was collected from the retroocular venous plexus after $12 \mathrm{~h}$ fasting. All samples were stored at $-80^{\circ} \mathrm{C}$ immediately for biochemical analysis.

\subsection{Thymus Index and Spleen Index}

All the mice were killed by cervical dislocation and then spleen and thymus of the mice were excised and weighed on the balance at the end of the drug administration experiment. Index = average weight/average body weight.

\subsection{Measurement of Tumor Weight and Tumor Inhibition Rate}

Tumors were dissected after mice sacrificed and washed with serile saline and weighed precisely at the end of the experiment and calculate the anti-tumor rate.

Inhibitory rate $/ \%)=$ (the mean tumor weight of control group - the mean tumor weight of treated group)/the mean tumor weight of control group $\times 100$.

\subsection{PI Staining}

The cell cycle distribution was analyzed by flow cytometry. After the mice sacrificed, tumor cells were harvested, washed twice with PBS and fixed in $70 \%$ ethanol, and stored at $4{ }^{\circ} \mathrm{C}$ for at least $18 \mathrm{~h}$, washed twice again and then incubated with RNase $30 \mathrm{~min}$ at $37^{\circ} \mathrm{C}$, subsequently added propidium iodide (PI, BD Biosciences, San Jose, CA, USA) at $4{ }^{\circ} \mathrm{C}$ in the dark for $10 \mathrm{~min}$. The stained cells were subjected to a BD FACSCalibur flow cytometer.

\subsection{Detection of T Lymphocyte Subpopulation}

$\mathrm{CD} 4^{+} \mathrm{T}$ cells and $\mathrm{CD} 8^{+} \mathrm{T}$ cells populations in thymus, tumor, spleen and blood was tested with PE-CD $4^{+}$and FITC-CD8 ${ }^{+}$antibodies. Thymocyte suspensions were produced by forcing the samples through a wire-mesh screen and incubated in RBC lysis buffer for 15 min to lyse red blood cells, then diluted with PBS. Following centrifugation (1500 rpm, $5 \mathrm{~min}$ ), lymphocytes were detected and then incubated with the antibodies for $30 \mathrm{~min}$ at $37^{\circ} \mathrm{C}$ in the dark. Cells were analyzed after PBS washing on a flow cytometer and analyzed with CELLQuest software (BD Biosciences, San Jose, CA, USA).

\subsection{Detection of IL-2, IFN- $\gamma$ and TNF- $\alpha$ in Peripheral Blood}

IL-2, IFN- $\gamma$ and TNF- $\alpha$ in serum of each group were assessed by ELISA Kit (Hufeng Biotech. Co., Shanghai, China) under the manufacturer's instruction. Then the plate was read on a BioRad Model 680 Microplate Reader at $450 \mathrm{~nm}$.

\subsection{Statistics Analysis}

All experiments data are expressed as means \pm SD. One-way analysis of variance (ANOVA) followed by the S-N-K test was used to determine the differences between groups under different conditions. $p$-Value less than 0.05 was considered statistically significant.

\section{Conclusions}

Se- $\beta$-lg exhibited a strong antitumor activity on S180 tumor-bearing mice in vivo, which could effectively protect the thymus and spleen from solid tumors, balance the proportions of $\mathrm{T}$ cells in 
peripheral blood, induce the apoptosis of S180 tumor cells via blocking cell cycle in G0/G1 phase and enhance the secretion of tumor-related cytokines. Our results indicated that Se- $\beta$-lg processes a better immunoenhancement effect than $\beta$-lg and a lower toxic effect than $\mathrm{SeO}_{2}$, which would provide a theoretical basis on its practical applications in food and drug industries.

Acknowledgments: The financial support provided by the National Science Foundation of China (31401663) is greatly appreciated.

Author Contributions: An-jun Liu conceived and designed the experiments; Su-jun Sun and Yan Zhang performed the experiments; Ying-ying Feng, Hai-yu Ji and Juan Yu analyzed the data; Su-jun Sun and Ying-ying Feng wrote the paper; Yan Zhang contributed reagents/materials/analysis tools; and all authors approved the final paper.

Conflicts of Interest: The authors declare no conflict of interest.

\section{References}

1. Palomo, M.; Gutierrez, A.M.; Perez-Conde, M.C.; Camara, C.; Madrid, Y. Se metallomics during lactic fermentation of Se-enriched yogurt. Food Chem. 2014, 164, 371-379. [CrossRef] [PubMed]

2. Skalickova, S.; Milosavljevic, V.; Cihalova, K.; Horky, P.; Richtera, L.; Adam, V. Selenium nanoparticles as a nutritional supplement. Nutrition 2017, 33, 83-90. [CrossRef] [PubMed]

3. Yao, Z.; Zhang, Y.; Li, H.; Deng, Z.; Zhang, X. Synergistic effect of Se-methylselenocysteine and vitamin E in ameliorating the acute ethanol-induced oxidative damage in rat. J. Trace Elem. Med. Biol. 2015, 29, 182-187. [CrossRef] [PubMed]

4. Yang, F.R.; Li, Y.; Zhang, X.H.; Wang, M.; Guo, H.R.; Ruan, W.J. Anticancer effect and mechanism of a Se-modified porphyrin Au(III) complex. Bioorg. Med. Chem. Lett. 2015, 25, 3592-3596. [CrossRef] [PubMed]

5. Avila, F.W.; Yang, Y.; Faquin, V.; Ramos, S.J.; Guilherme, L.R.; Thannhauser, T.W.; Li, L. Impact of selenium supply on Se-methylselenocysteine and glucosinolate accumulation in selenium-biofortified Brassica sprouts. Food Chem. 2014, 165, 578-586. [CrossRef] [PubMed]

6. Chen, D.; Sun, S.; Cai, D.; Kong, G. Induction of mitochondrial-dependent apoptosis in T24 cells by a selenium (Se)-containing polysaccharide from Ginkgo biloba L. leaves. Int. J. Biol. Macromol. 2017, 101, 126-130. [CrossRef] [PubMed]

7. Wang, Y.; Li, Y.; Liu, Y.; Chen, X.; Wei, X. Extraction, characterization and antioxidant activities of Se-enriched tea polysaccharides. Int. J. Biol. Macromol. 2015, 77, 76-84. [CrossRef] [PubMed]

8. Wang, Y.; Chen, J.; Zhang, D.; Zhang, Y.; Wen, Y.; Li, L.; Zheng, L. Tumoricidal effects of a selenium (Se)-polysaccharide from Ziyang green tea on human osteosarcoma U-2 OS cells. Carbohydr. Polym. 2013, 98, 1186-1190. [CrossRef] [PubMed]

9. Liu, Y.; Sun, J.; Rao, S.; Su, Y.; Li, J.; Li, C.; Xu, S.; Yang, Y. Antidiabetic activity of mycelia selenium-polysaccharide from catathelasma ventricosum in STZ-induced diabetic mice. Food Chem. Toxicol. 2013, 62, 285-291. [CrossRef] [PubMed]

10. Mao, G.H.; Ren, Y.; Li, Q.; Wu, H.Y.; Jin, D.; Zhao, T.; Xu, C.Q.; Zhang, D.H.; Jia, Q.D.; Bai, Y.P.; et al. Anti-tumor and immunomodulatory activity of selenium (Se)-polysaccharide from Se-enriched Grifola frondosa. Int. J. Biol. Macromol. 2016, 82, 607-613. [CrossRef] [PubMed]

11. Yuan, C.; Wang, C.; Wang, J.; Kumar, V.; Anwar, F.; Xiao, F.; Mushtaq, G.; Liu, Y.; Kamal, M.A.; Yuan, D. Inhibition on the growth of human MDA-MB-231 breast cancer cells in vitro and tumor growth in a mouse xenograft model by Se-containing polysaccharides from Pyracantha fortuneana. Nutr. Res. 2016, 36, 1243-1254. [CrossRef] [PubMed]

12. Indyk, H.E.; Hart, S.; Meerkerk, T.; Gill, B.D.; Woollard, D.C. The $\beta$-lactoglobulin content of bovine milk: Development and application of a biosensor immunoassay. Int. Dairy J. 2017, 73, 68-73. [CrossRef]

13. He, Z.; Zhu, H.; Xu, M.; Zeng, M.; Qin, F.; Chen, J. Complexation of bovine $\beta$-lactoglobulin with malvidin-3-O-glucoside and its effect on the stability of grape skin anthocyanin extracts. Food Chem. 2016, 209, 234-240. [CrossRef] [PubMed]

14. Murphy, R.W.; Farkas, B.E.; Jones, O.G. Effect of crosslinking on the physical and chemical properties of beta-lactoglobulin (Blg) microgels. J. Colloid Interface Sci. 2017, 505, 736-744. [CrossRef] [PubMed] 
15. Jia, J.; Gao, X.; Hao, M.; Tang, L. Comparison of binding interaction between $\beta$-lactoglobulin and three common polyphenols using multi-spectroscopy and modeling methods. Food Chem. 2017, 228, 143-151. [CrossRef] [PubMed]

16. Guo, Y.; Harris, P.; Kaur, A.; Pastrana, L.; Jauregi, P. Characterisation of $\beta$-lactoglobulin nanoparticles and their binding to caffeine. Food Hydrocoll. 2017, 71, 85-93. [CrossRef]

17. Livney, Y.D. Milk proteins as vehicles for bioactives. Curr. Opin. Colloid Interface Sci. 2010, 15, 73-83. [CrossRef]

18. Ren, Y.; Zhao, T.; Mao, G.; Zhang, M.; Li, F.; Zou, Y.; Yang, L.; Wu, X. Antitumor activity of hyaluronic acid-selenium nanoparticles in heps tumor mice models. Int. J. Biol. Macromol. 2013, 57, 57-62. [CrossRef] [PubMed]

19. Cao, J.; Hou, D.; Lu, J.; Zhu, L.; Zhang, P.; Zhou, N.; Chen, K. Anti-tumor activity of exopolysaccharide from rhizopus nigricans ehrenb on s180 tumor-bearing mice. Bioorg. Med. Chem. Lett. 2016, 26, 2098-2104. [CrossRef] [PubMed]

20. Kim, J.; Park, G.; Lee, S.; Hwang, S.W.; Min, N.; Lee, K.M. Single wall carbon nanotube electrode system capable of quantitative detection of $\mathrm{CD}^{+} \mathrm{T}$ cells. Biosens. Bioelectron. 2017, 90, 238-244. [CrossRef] [PubMed]

21. Hiraoka, N. Tumor-infiltrating lymphocytes and hepatocellular carcinoma: Molecular biology. Int. J. Clin. Oncol. 2010, 6, 544-552. [CrossRef] [PubMed]

22. Ghosh, S.; Sarkar, M.; Ghosh, T.; Guha, I.; Bhuniya, A.; Biswas, J.; Mallick, A.; Bose, A.; Baral, R. Absence of $\mathrm{CD}^{+} \mathrm{T}$ cell help generates corrupt $\mathrm{CD} 8^{+}$effector $\mathrm{T}$ cells in sarcoma-bearing Swiss mice treated with NLGP vaccine. Immunol. Lett. 2016, 175, 31-39. [CrossRef] [PubMed]

23. Godet, Y.; Fabre, E.; Dosset, M.; Lamuraglia, M.; Levionnois, E.; Ravel, P.; Benhamouda, N.; Cazes, A.; Le Pimpec-Barthes, F.; Gaugler, B.; et al. Analysis of spontaneous tumor-specific CD4 T-cell immunity in lung cancer using promiscuous hla-dr telomerase-derived epitopes: Potential synergistic effect with chemotherapy response. Clin. Cancer Res. 2012, 18, 2943-2953. [CrossRef] [PubMed]

24. Oh, J.G.; Hwang, D.J.; Heo, T.H. Direct regulation of IL-2 by curcumin. Biochem. Biophys. Res. Commun. 2017, 495, 300-305. [CrossRef] [PubMed]

25. Ruan, B.Y.; Chen, S.N.; Hou, J.; Huang, B.; Laghari, Z.A.; Li, L.; Nie, P. Two type II IFN members, IFN- $\gamma$ and IFN- $\gamma$ related (rel), regulate differentially IRF1 and IRF11 in zebrafish. Fish Shellfish Immunol. 2017, 65, 103-110. [CrossRef] [PubMed]

26. Umapathy, D.; Krishnamoorthy, E.; Mariappanadar, V.; Viswanathan, V.; Ramkumar, K.M. Increased levels of circulating (TNF- $\alpha$ ) is associated with (-308G/A) promoter polymorphism of TNF- $\alpha$ gene in Diabetic Nephropathy. Int. J. Biol. Macromol. 2017, in press. [CrossRef] [PubMed]

Sample Availability: Not available.

(C) 2017 by the authors. Licensee MDPI, Basel, Switzerland. This article is an open access article distributed under the terms and conditions of the Creative Commons Attribution (CC BY) license (http://creativecommons.org/licenses/by/4.0/). 